\title{
Determinants of occupational mobility: the importance of place of work
}

David McCollum ${ }^{\mathrm{a}}$, Ye Liu ${ }^{\mathrm{ab}}{ }^{*}$, Allan Findlay ${ }^{\mathrm{a}}$, Zhiqiang Feng ${ }^{\mathrm{c}}$, Glenna Nightingale ${ }^{\mathrm{a}}$

\begin{abstract}
This research focuses on individual and place-based determinants of occupational mobility in Scotland 2001-2011. The originality of the paper relates to the importance of workplace location, rather than residential locations, on occupational mobility, and in the questioning of the idea that spatial mobility accelerates occupational mobility. The findings also indicate that skill level and employment in 'knowledge intensive' sectors are key determinants of career progression. Urban career escalator effects are found to be particularly evident for higher skilled workers. The findings point to the importance of spatial sophistication and sectoral sensitivity in understandings of occupational mobility.
\end{abstract}

Keywords: escalator regions, place of work, migration, occupational mobility, Scotland

JEL classification: J24, J61, J62, R23

\footnotetext{
a School of Geography and Geoscience, University of St Andrews, Irvince Building, North Street, St Andrews KY16 9AL, UK.

${ }^{\mathrm{b}}$ School of Geography and Planning, Sun Yat-sen University, Xingang W Rd, Haizhu, Guangzhou, 510275, China.

${ }^{\mathrm{c}}$ Institute of Geography, School of GeoSciences, University of Edinburgh, Drummond Street, Edinburgh, EH8 9XP, UK

* Corresponding author
}

\section{Acknowledgement}

The help provided by staff of the Longitudinal Studies Centre - Scotland (LSCS) is acknowledged. The LSCS is supported by the ESRC/JISC, the Scottish Funding Council, the Chief Scientist's Office and the Scottish Government. The authors alone are responsible for the interpretation of the data. Census output is Crown copyright and is reproduced with the permission of the Controller of HMSO and the Queen's Printer for Scotland.

This work was supported by the ESRC under Grant ES/G027153/1.

\section{Introduction}

The progression of workers along the occupational hierarchy across the course of their careers has long been a concern of policymakers and social scientists alike. This research focuses on individual and place based determinants of occupational mobility, and their relationship to spatial mobility. The link between spatial and occupational mobility is an intriguing one as the migration of individuals already well disposed towards upward occupational mobility, to places 
that offer extraordinary opportunities for it, raises the theoretically stimulating and policy pertinent question of how individual and place effects and spatial mobility combine to generate certain career outcomes for specific types of people in particular types of places. The research seeks to address the following research questions:

1. Which individual level characteristics are associated with upward occupational mobility?

2. Is there evidence of place-based effects in the determinants of upward occupational mobility?

3. Is spatial mobility a driver of upward occupational mobility?

\section{Literature review}

The notion that career success is and ought to be determined chiefly by one's talents and efforts is inherent to understandings of social justice and economic productivity. As such the ability and propensity of individuals to move up or down the social ladder depending on their achievements has long been one of the foremost issues in the social sciences (Lipset and Bendix, 1959). In practice social mobility is often empirically assessed through measures of occupational mobility, as this reflects shifts in one's standing on the socio-economic ladder (broadly defined as changes in occupation over a given time period). This research sits within the body of literature that is concerned with the determinants of occupational mobility, and the roles of place-based and individual characteristics in these processes (Fielding, 1992; Gordon, 2015; Newbold and Brown, 2012).

Despite being the focus of much discussion (Fielding, 1992; Gordon et al, 2015; van Ham et al, 2012; Savage, 1988), the nature of relationship between spatial and social mobility remains unresolved. Whilst conceptually intriguing, a longstanding challenge faced by scholars in this realm relates to the availability of data sources and methodological approaches that allow for the empirical definition and disentanglement of the various factors that 'produce' occupational mobility. This analysis draws on innovative methodological techniques to explore these relationships through the empirical lens of occupational mobility in Scotland 2001-2011 using the census-based Scottish Longitudinal Study (SLS) dataset. Prior to these being explained, the following section provides a review of what the research literature says about how individual and place effects and spatial mobility relate to occupational mobility. 


\section{Occupational mobility: individual-level factors}

Ideally, workers should progress within the labour market over time as they acquire the education, experience and skills that enable them to undertake increasingly qualified tasks (Rooth and Ekberg, 2006). In a meritocracy this process of workers moving up (and down) occupational categories would be based on their efforts and abilities. However career outcomes are patently based on more than just merit, and as such the research literature has focused on issues such as persistent gender and ethnic inequalities in occupational mobility (Dex et al, 2008; Fleming et al, 2016). Setting aside wider structural inequalities (Crawford et al, 2011), research undertaken in various spatial and temporal contexts points to a number of key individual factors consistently being determinants of occupational progression.

Age is one important predictor of occupational mobility: career progression is faster at early stages, while careers stabilize later as workers tend to reach 'occupational maturity' (Manzoni et al, 2014). Whilst the magnitude of the effect is decreasing, gender is still an important determinant of occupational mobility, mainly due to women's careers being sensitive to family related factors such as childbearing and the career interruptions and reduced working hours that are associated with these events (Blossfeld and Hakim, 1997). The research literature also points to education (van Ham et al, 2012; Sicherman and Galor, 1990) and social class background being powerful determinants of career success (Härkönen and Bihagen, 2011), with the relative strengths of these effects varying spatially and temporally (Tolsma and Wolbers, 2014). Finally, whilst difficult to quantify, Ng et al (2007) and Gordon (2015) have highlighted how individual personality traits, career interests and ambitions, values and attachment styles can influence the mobility of workers within the occupational hierarchy.

\section{Occupational mobility: place-based factors}

Whilst it is widely accepted that individual attributes such as career ambitions play an important role in shaping career outcomes, economic and urban geographers and regional economists have emphasised the ways in which locational factors influence occupational trajectories. Local labour market 'tightness' is one such factor, and occupational mobility is procyclical, meaning that it is greater during recovery and boom periods and lower during recessions (Roosaar et al, 2014). These dynamics relate to the local geographies of economic 
performance, since places which perform better across the business cycle and have more buoyant labour markets in turn generate higher rates of career progression (Gordon et al, 2015). Another factor is size: it is widely recognised that earnings and rates of career progression are significantly higher in large metropolitan areas than in smaller urban and rural locations, largely due to high productivity levels and a concentration of skilled workers in these locales (Brown and Newbold, 2012; Glaeser and Mare, 2001). These points reasonably infer that the characteristics of the labour market within which one is embedded are a key determinant of occupational mobility. However most studies that incorporate locational factors into analysis of social mobility focus on where people live rather than where they work. As discussed in more detail below, this research is innovative in that it includes both place of work and place of residence as potential determinants of career progression.

The literature relating to so-called world cities is also relevant to understanding the role of certain city-regions in career progression as they have long been recognised as points of destination for large numbers of domestic and international migrants due to the variety and quality of employment opportunities they offer (Friedmann, 1986). These ideas are of relevance to the Scottish context, since Edinburgh, and to a lesser extent Glasgow, are increasingly being recognised as offering positive opportunities for career progression and as such attract migrants from the rest of the UK and further afield (van Ham et al, 2012). This analysis investigates whether the premise that larger urban areas, particularly bigger cities, offer relatively beneficial rates of upward occupational mobility holds in the Scottish context. The discussion now turns to the relationship between spatial and occupational mobility.

\section{Occupational mobility and spatial mobility}

Migration could conceivably enhance opportunities for occupational mobility for those who move by providing a means to achieve better returns on their investment in education and skills by relocating to the places offering the best chances of rapid promotion. Research supports the idea that most longer distance moves are motivated by economic factors, and those who have the desire and ability to gain most from such mobility (the relatively young, skilled and ambitious) display the greatest propensity to migrate (Lindstrom and Ramirez, 2010). As such, those locations that are best placed to offer rapid career progression should attract those who are best qualified to achieve it: so spatial mobility might be thought to be related to positive 
individual and place based determinants of occupational mobility. This spatially sensitive conceptual framework forms the rationale behind the third of the research questions posed above.

The notion that the migration of individuals that are well placed to achieve occupational mobility, to places that are well placed to offer it, sits within the literature on so-called escalator regions. This term was first coined by the geographer Tony Fielding in 1992 to refer to those urban centres that offer exceptional opportunities to climb the occupational hierarchy, and thus attract skilled and ambitious migrants. This framework was originally applied to London and the wider South East of England and encapsulates the notion that those with greatest 'promotion potential' are attracted to those regions which act as the fastest 'escalators' in terms of career progression. According to Fielding's (1992) original exposition, the following three features defined escalator regions. Firstly, acting as a magnet for those with greatest promotion potential (stepping on the escalator). Secondly, providing residents with accelerated upward social mobility (promoted by the escalator). Finally, the loss via out migration of some of the initial migrants at later point in their careers (stepping off the escalator).

Fielding's original framework has since formed the basis of a number of studies, predominantly in a European and North American context, into the influence of spatial mobility on occupational mobility (Brown and Newbold, 2012; van Ham et al, 2012; King et al, 2015). However there remains some uncertainty regarding the role that migration can have in career progression. Some have argued that the self-selectivity of migration means that migrants in escalator regions experience accelerated occupational mobility relative to non-migrants, as a consequence of being more highly qualified (van Ham et al, 2012). Others have argued that it is not because people are migrants that they benefit from the escalator process in specific cityregions, but that it is because migration is positively selective of the most highly educated that the effect is observed, and that they advance no more quickly than equivalently well qualified and ambitious individuals originating from within the escalator region (Findlay et al, 2008). Others contend that it is really those working in particular kinds of skilled jobs and in specific sectors that gain most from career escalator effects (Gordon et al, 2015). This analysis tests these ideas, along with the claim that similar escalator processes operate in cities that do not occupy the upper reaches of the global city hierarchy (Gordon et al, 2015). 
Efforts to interrogate the spatial-social mobility nexus can fruitfully draw lessons from the growing literature that focuses on 'mobilities' in migration studies (King, 2012), as this relatively nascent paradigm emphasises the inherent connections between spatial mobility and other forms of mobility, such as career progression. Emphasis on the point that physical mobility is frequently motivated by the prospect of social mobility (Glick-Schiller and Salazar, 2013) encourages consideration of the ways in which moving between places can be a source of status and power, and that critically these processes operate in an uneven manner (Schiller and Urry, 2006). This recognition helps to widen understandings of mobility (and immobility) as occurring within particular social and economic relationships, rather than just purely in relation to geographic borders (Kalir, 2013). The new mobilties paradigm also encourages a rejection of longstanding binaries in the social sciences, particularly in this case between migration and other forms of spatial mobility, such as commuting (Halfacree, 2012). Such a conceptual lens is thus a helpful means through which the outcomes of empirical research into the determinants of career process and outcomes can be theorised.

\section{Data and methods}

\section{Methodological approach: overview}

By definition, analyses of geographic and occupational mobility rely on the availability of longitudinal data at suitable temporal and spatial scales. In fact it was the initial linking of decennial national census records in England and Wales through the ONS Longitudinal Study that enabled Fielding (1992) to propose and empirically verify his escalator region hypothesis. The current analysis makes use of the Scottish Longitudinal Study (SLS), a census derived 5.3 per cent representative sample of the population of Scotland that allows for the circumstances of the same individuals to be tracked between the 1991, 2001 and 2011 censuses (Boyle et al, 2009). In this instance the study sample consisted of SLS members who were aged 16-45 in 1991 and who held a valid socio-occupational classification at each of the 1991, 2001 and 2011 censuses (summary statistics in Appendix Table 1).

The chief focus of analysis was the determinants of career success, as measured through changes in job status level between 2001 and 2011. The statistical analysis included measures to identify individual level, place based and migration related potential determinants of 
occupational mobility. The study examines how a person's residence and workplace at the start of a decade influences his/her job status change over the subsequent decade. An ordinary least squares (OLS) regression model examining the determinants of a person's occupational mobility between 2001 and 2011 can be written as follows:

$$
\Delta \log \left(J_{01-11}^{\prime}\right)=U_{0 I}^{\prime} \delta+M_{01}^{\prime} \varphi+S_{01}^{\prime} \phi+X_{01}^{\prime} \beta+J_{01}^{\prime} \lambda+\Delta \log \left(J_{91-01}^{\prime}\right) v+\varepsilon
$$

where $\Delta \log \left(J_{01-11}\right)$ represents the job status change between 2001 and $2011 . U_{01}$ denotes the place of residence and the place of work in 2001; $M_{01}$ indicates the presence of migration over the decade of 1991-2001; $S_{01}$ denotes the knowledge-intensive index of an individual's industrial sector in 2001; $X_{01}$ denotes a vector of other individual-specific characteristics in $2001 ; J_{01}$ denotes job status level in 2001 , which is used to capture both floor and ceiling effects (Gordon et al, 2015; van Ham et al, 2012); $\Delta \log \left(J_{91-01}\right)$ represents the job status change between 1991 and 2001, which was included in the model to further control for unobserved heterogeneity (e.g. career ambition); and $\varepsilon$ denotes unobservable errors.

It is worth noting that, although the SLS is a longitudinal dataset in nature, this study conducted a cross-sectional analysis instead of a longitudinal analysis. One may argue that it is possible to make two repeated observations of individuals' job status change over the period of 19912011 and to examine factors underlying individuals' job status change using a longitudinal analysis. However, using a longitudinal analysis such as a first-difference approach is problematic in this case (Wooldridge, 2012), because key explanatory variables in regressions (i.e. place of residence, place of work and the presence of migration) do not vary much over time (less than ten percent respondents reported the presence of migration over the periods of 1991-2001 and 2001-2011). Therefore, a cross-sectional type analysis was used to examine the links between key explanatory variables and individuals' job status change over the decade of 2001-2011.

\section{$\underline{\text { Refined measure of occupational mobility }}$}

Many analyses of occupational mobility rely on a relatively crude measure of career progression, that is upward movement into one of the top main social class groupings from a lower social class grouping (Findlay et al, 2008; van Ham et al, 2012). The more refined analysis developed in this research follows Gordon et al (2015) in accounting for movement 
across a large number of discrete occupational categories using an innovative measure of job status. Such a perspective is of value since in the study sample nearly four fifths of those in a high skilled socio-economic group in 2001 remained within this category by 2011 , and thus any career progression made by these individuals 2001-2011 would not be captured through traditional measures of occupational mobility.

Rather than rely on broad socio-economic classifications, this research operates on the logic that the value that the labour market attaches to occupations through wages is an effective measure of occupational standing and thus change. This approach, inspired by Nickell (1982) and Gordon et al (2015), reasons that market evaluations (i.e. wages) are a more apposite reflection of relevant labour market supply and demand factors than the more value laden judgements concerning which jobs are superior that class-based analyses entail. Unfortunately, as a census-based dataset, the SLS does not contain information on income. Consequently this analysis uses the Labour Force Survey, and controls for inflation, to construct estimates of earnings specific to particular occupations (Dibben and Clemens, 2012). As SOC information is highly detailed (81 groups 2001-2010 and 90 in 2011-2015), the synthesised weekly wage can form the basis of a job status index (van Ham and Manley, 2015). Upward occupational mobility in this study is defined as having an occupation with a higher job status index in 2011 than 2001. Individuals' job status changes over this decade are regressed on a set of other census-based indicators in order to investigate the determinants of occupational mobility.

\section{$\underline{\text { Spatial sophistication of analysis }}$}

Place and migration naturally sit at the centre of understandings of the spatial-social mobility nexus. Much research, through focusing on the potential escalator effect of London and the South East of England has simply aggregated these two Government Office Regions and compared occupational trajectories in this large area (population 18 million) against those in the rest of the country (Champion, 2012; Fielding, 2007; Findlay et al, 2008; Reuschke, 2015). Focusing on the spatial-social mobility dynamic in Scotland, this analysis explores potential escalator effects across a range of lower level geographies. In this case four geographic indicators used were Glasgow, Edinburgh, other large urban areas, and the rest of Scotland. The two main cities were analysed separately from each other and from other larger urban areas as these are the two most likely candidates for escalators in Scotland. Edinburgh is Scotland's 
capital city and is the seat of the country's devolved government. The economically buoyant city hosts the headquarters of a range of public sector, financial and other business institutions. Glasgow is the biggest city in Scotland and is one of the largest cities in the UK. The former industrial powerhouse suffered widespread job losses due to post-war economic restructuring, but has since reinvented itself as a major retail, entertainment and cultural hub. In career terms, the attractiveness of these cities to migrants lies in their enhanced opportunities for employment and their concentration of higher ranking jobs. Edinburgh has a much higher proportion of jobs in the top main three standard occupational classifications than both the Scottish and UK averages (57\%, 43\% and 46\% respectively). Average earnings also far exceed the Scottish and UK averages and the city has three times the volume of finance jobs than Scotland and the UK generally (ONS, 2017a). Whilst Glasgow's labour market is not as buoyant as Edinburgh's the city is home to a higher share of top ranking jobs than the Scottish and UK averages and has an impressive jobs density (1.04). The city has a relatively high share of jobs in the information and communication, finance and health sectors relative to the rest of Scotland and UK (ONS, 2017b). The 'other urban area' category contains places with a population in excess of 125,000 : the cities of Dundee and Aberdeen and some densely populated parts of the Central Belt (see Fraser of Allander Institute, 2015 for details of economic performance of Scotland's cities). Finally the rest of Scotland category contains those locations with a population smaller than 125,000 .

A key contribution of this research in terms of spatial indicators is that it includes analysis of occupational mobility by place of work as well as place of residence. Research on escalator effects thus far has only examined the effect of where people live on their occupational trajectories. This issue is negated in research that uses broad geographic indicators, such as Government Office Regions, since sample members will most likely live and work within the same general region. However at finer geographies this disparity becomes significant since many individuals live in one type of place and commute to another for work (such as is the case in Glasgow). This analysis allows, for the first time, for this distinction to be identified and scrutinised. This is of value since the nature of the local labour market that one is embedded in is potentially a greater determinant of career progress, and less closely correlated with individual characteristics, than where one resides. By uniquely incorporating both, this analysis allows for detection of the extent to which 'place matters' according to where one works verses 
lives, and thus can contribute to an enhanced understanding of the nature of place based predictors of occupational mobility.

An additional aspect of importance concerning the spatial-social mobility nexus relates to how migration is measured. A challenge associated with assessing the migration experiences of members of census based longitudinal datasets is that the significant time lapse between censuses means that researchers only have information about respondents' location (and occupational status) at ten year intervals, with subsequent significant gaps in understanding of their circumstances between these periods. As such researchers must turn to imperfect indictors of spatial mobility. One such proxy is country of birth. As migration is a selective process, people who migrate from other parts of the UK or other countries to Scotland are hypothesised to be relatively skilled and ambitious and therefore perform well in terms of labour market mobility (van Ham et al, 2012).

Whilst a general indicator of the presence of migration, the main limitations of the country of birth measure are that it does not give an indication of when someone actually moved to Scotland and it cannot account for mobility within Scotland. For these reasons a further measure of geographic mobility was developed: presence of migration. This study classified individuals who changed their residential location by a distance greater than $40 \mathrm{~km}$ over the decade between the 1991 and 2001 censuses as migrants. This distance threshold was set so as to filter out short-distance residential housing related mobilities that most likely do not involve a change of workplace. For robustness the analysis also tests the effects of presence of migration on subsequent occupational mobility using a variety of distance cut-offs (Abreu et $a l, 2014)$.

\section{$\underline{\text { Sectoral and gender sensitivity }}$}

This analysis incorporated a knowledge intensive index to reflect the fact that career progression rates vary across different industries (Glaeser and Mare, 2001; Gordon et al, 2015). This index assessed the knowledge intensity of an individual's industrial sector based on calculations of the proportion of degree holders in each two-digit Standard Industrial Classification sector. The value of this perspective is that it enables the modelling to account 
for the relative effect of working in particular sectors, along with other potential determinants of occupational mobility. The modelling of job status change was carried out separately for male and female sample members, given the significant and longstanding gender differentials that exist in terms of earnings and occupational mobility patterns and processes (Dex et al, 2008; Xu et al, 2006). This gender sensitivity was especially important since existing analyses have pointed to women's career progression being especially sensitive to escalator effects (Fielding and Halford, 1993), potentially due to larger labour markets being more open to female advancement than provincial ones (Bruegel, 2000).

\section{$\underline{\text { Temporal sequencing of events }}$}

The motivation for assessing spatial mobility 1991-2001 against subsequent occupational mobility 2001-2011 was to negate the common criticism that this type of research does not account for the direction of influence i.e. the timing and sequencing of changes in location and job status. Many individuals will experience both spatial and occupational mobility over a tenyear period, but the decade gap between censuses means that researchers only have access to information about their location and job status at beginning and end of this period. As such a longstanding challenge is that it is difficult to infer whether occupational mobility precedes, occurs in conjunction with, or follows spatial mobility (Findlay et al, 2009). A pragmatic response to this quandary is to assess spatial and occupational mobility over separate consecutive time periods, as is the case in this analysis. This perspective improves on the conventional approach of assessing social and spatial mobility over the same period (Gordon et al, 2015; Newbold and Brown, 2012; Fielding, 1992). A drawback however of this approach is that it may fail to fully capture the relationship between spatial and social mobility due to the potentially lengthy time lapses between identifiable events.

\section{Accounting for selection bias}

A problem that has long haunted the analysis of economic returns to migration is the selfselection issue (Glaeser and Mare, 2001; Newbold and Brown, 2012). Personal attributes such as ability and ambition influence both the propensity to engage in spatial mobility and achieve occupational mobility. Combining the effects of treatment (i.e. the presence of migration or working/living in escalator regions) and selection could lead to an upward bias in the estimates 
of the escalator effect (or migration effect). This problem is partially addressed in this research through the use of lagged dependent variables (job status level in 2001 and occupational mobility 1991-2001) in the regressions. Propensity score matching techniques are used to control for either spatial selectivity or migration selectivity due to observed characteristics such as educational qualification (Newbold and Brown, 2012; Rosenbaum and Rubin, 1983). However, selection bias could not be completely removed by controlling for unobserved ability and ambition due to the following reasons. First, proxy variables for ability and ambition are not available in census-based SLS dataset. Second, fixed-effect panel data models are not feasible due to the structure of the dependent variable (which is the change of occupational status over a decade rather than a certain level of occupational status). Third, there is a lack of a suitable instrumental variable that predicts the place of work or residence (or migration) and is orthogonal to unobserved ability.

\section{Results}

\section{The geography of occupational mobility}

Table 1 shows levels of upward mobility in Scotland into the top two main occupational categories (professional and managerial) 2001-2011. A cursory examination of these figures leads to at least three observations. First, it appears that Scotland's capital city, Edinburgh, enjoys the highest upward mobility, although it is marginally beaten by Glasgow for males by place of work. Second, for Glasgow, other large urban areas and the rest of Scotland, place of work data seem to produce markedly higher measures of occupational mobility than do place of residence data. This raises the important question of why such a difference should be evident. Third, when workplace data are used, the category of 'the rest of Scotland' made up of rural areas and small towns show lower levels of upward mobility than elsewhere. This points to a fundamental challenge to the idea that Scotland is as meritocratic as some would have hoped, since it seems evident that those working in large parts of the country have a poorer chance of advancement, at least if they remained stationary. It might lead, however, to the expectations that on the one hand migration to areas of better opportunities could resolve the geographic differences evident in the table, or on the other hand the commuting to work in Edinburgh, Glasgow or other large urban centres could at least moderate the locational career disadvantages that seem to be associated with living in rural Scotland. Another notable figure 
in Table 1 is the much higher rates of upward occupational mobility amongst longer distance movers $(23.95 \%$ versus $15.90 \%$ for males, and $20.75 \%$ versus $15.25 \%$ for females).

Table 1: The percentage of SLS members moving from lower into high skill occupational categories in 2001-2011 ${ }^{\mathrm{a}}$, by place of work and residence in 2001 and by the presence of migration $(40 \mathrm{~km}+)$ 1991-2001

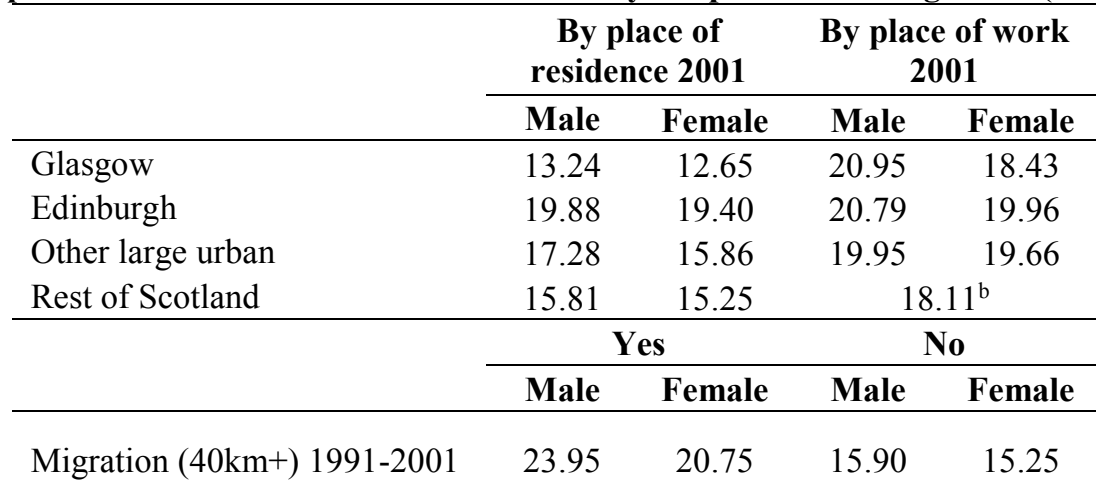

Note: a. High skill occupation: NS-SEC groups $1 \& 2$, lower skill categories: NS-SEC groups 3, 5, $6 \& 7$. NS-SEC group 4 (small employers and own account workers) excluded as this covers a variety of skill levels. b. These statistics differentiated by gender are not available because the corresponding cell counts are less than 10 .

Source: Author's analysis of the SLS

In order to investigate these ideas in more depth, the researchers examined the reasons that might underlie uneven geographies of upward occupational mobility in Scotland. One possible line of enquiry was to explore whether geographic variations in individual characteristics (either based on structural divisions in society or inequalities in the organisation of labour market opportunities) could account for variations in personal advancement. A second line of inquiry was to move away from the crude measure of occupational mobility employed in Table 1 and to base inferential statistical examination on a more sophisticated continuous measure of occupational advancement as previously introduced in the methodology section. Interestingly, as shown in Appendix Table 2, those working in Glasgow seemingly enjoy the highest rate of upward occupational mobility, with those working in Edinburgh apparently having the lowest rates of upward mobility. This result is another motivating factor behind the use of multiple regression modelling.

\section{Determinants of occupational mobility: all workers}

The analysis now draws on OLS regression modelling to investigate the extent to which individual-level factors, place-based factors, and geographic mobility are determinants of occupational mobility. The results shown in Table 2 underline the value of assessing 
occupational mobility according to place of work as well as place of residence: living in particular places is not necessarily associated with better rates of career progression, but working in larger urban areas is. Glasgow workers experience the highest upward mobility (0.225 and $0.504 \log$ points for men and women, respectively). Edinburgh workers enjoy higher level of occupational progress than those working in the rest of Scotland (0.156 and $0.383 \log$ points). The results confirm that place of work appears to exert particular influence on occupational mobility in the case of women's careers. As might be expected, working in knowledge intensive industries and higher levels of education are positively associated with upward occupational mobility (Gordon et al, 2015). Again, in line with the existing literature, familial circumstances (marriage and the existence of children) impact differently on the career outcomes of and women (Dex et al, 2008). Being married and living with dependent children are positively associated with the rate of male workers' career progression, but living with dependent children is a deterrent of female workers' upward occupational mobility. Concern with the existence of ceiling effects is given credence by the regression output, with already being in a higher ranking job in 2001 and already having experienced career progression 19912001 seemingly acting against upward occupational mobility 2001-2011. 


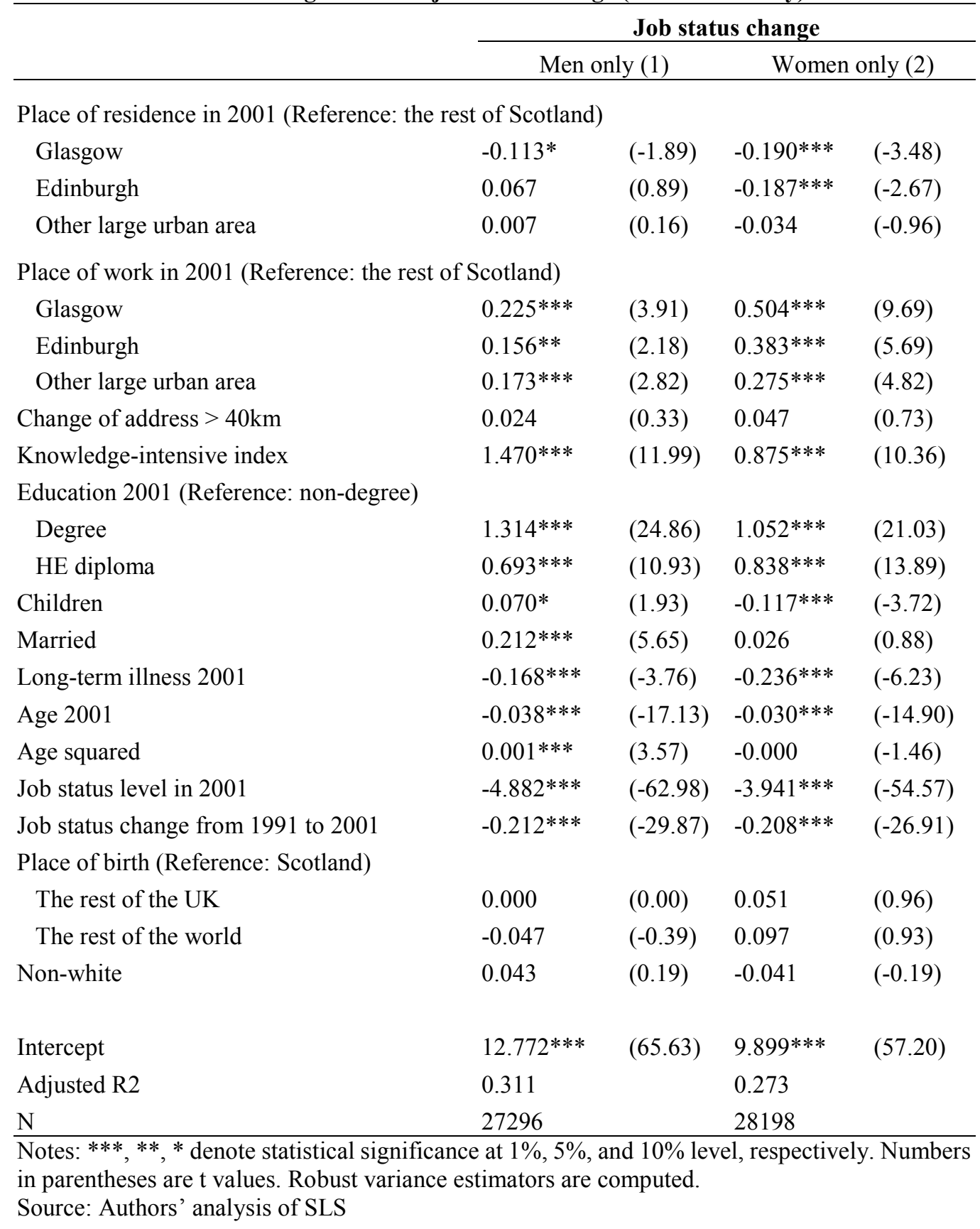

In terms of spatial mobility, neither migration nor country of birth appear to be important determinants of occupational mobility. A possible explanation for the migration variable not being statistically significant is that the $40 \mathrm{~km}$ cut off is an arbitrary way of separating longer distance migration from shorter distance residential mobility. As a robustness check the distance cut offs were changed to $20 \mathrm{~km}$ and $60 \mathrm{~km}$. However these changes did not result in migration becoming a more significant determinant of occupational mobility, suggesting that engaging in longer distance spatial mobility does not favour occupational mobility according to the particular measures used in this analysis. Another explanation for the absence of 
migration effect is that the direction of migration is not taken into account. For example, people moving from non-escalator to escalator regions are expected to experience higher rates of upward mobility compared with those moving in the opposite direction. However, when residential locations in both 1991 and 2001 were included in the regressions, no evidence suggested that the direction of migration mattered for individuals' occupational mobility (results are shown in Appendix Table 3).

In another robustness check, the baseline models were re-estimated using only place of work or place of residence. The results shown in Table 3 are consistent with those that have been found from Table 2: living in escalator regions is not necessarily linked to accelerated upward social mobility, but working in escalator regions and other large urban areas is. Propensity score matching estimates, which are used to address selection bias due to individual observed characteristics (such as educational qualifications), support the results from OLS regressions (Table 4). First, people working in larger urban areas (especially those working in Glasgow and Edinburgh) experience higher rates of upward occupational mobility compared with people working elsewhere. Second, merely living in larger urban areas does not facilitate upward occupational mobility. Third, the presence of migration is not significantly associated with occupational mobility. In this sense, results from the OLS regressions are robust when spatial selectivity and migration selectivity are partially controlled. 
Table 3: Regression of job status change (place of residence or place of work only instead of both)

\section{Place of residence only}

Men only (3)

Place of residence in 2001 (Reference: the rest of Scotland)

$\begin{array}{lllll}\text { Glasgow } & -0.037 & (-0.66) & 0.058 & (1.22) \\ \text { Edinburgh } & 0.132 * * & (2.11) & 0.029 & (0.54) \\ \text { Other large urban area } & 0.057 & (1.48) & 0.075^{* *} & (2.25)\end{array}$

Place of work in 2001 (Reference: the rest of Scotland)

Glasgow

Edinburgh

Other large urban area

Individual variables

Yes

\begin{tabular}{|c|c|c|c|c|c|c|}
\hline Intercept & $12.744 * * *$ & $(65.49)$ & $9.864 * * *$ & $(56.90)$ & $12.752 * * * \quad(65.64)$ & $9.867 * * * \quad(57.15)$ \\
\hline Adjusted R2 & 0.310 & & 0.270 & & 0.311 & 0.273 \\
\hline $\mathrm{N}$ & 27296 & & 28198 & & 27296 & 28198 \\
\hline
\end{tabular}

Notes: $* * *, * *, *$ denote statistical significance at $1 \%, 5 \%$, and $10 \%$ level, respectively. Numbers in parentheses are $\mathrm{t}$ values. Robust variance estimators are computed.

Source: Authors' analysis of SLS 
Table 4: Propensity score matching estimates of escalator effect and migration effect on job status change

\begin{tabular}{|c|c|c|c|c|}
\hline \multirow[b]{3}{*}{$\begin{array}{l}\text { Place of work in 2001: large urban areas (including Edinburgh and } \\
\text { Glasgow) vs the rest of Scotland }\end{array}$} & \multicolumn{4}{|c|}{ ATT } \\
\hline & \multicolumn{2}{|c|}{ Men only } & \multicolumn{2}{|c|}{ Women only } \\
\hline & $0.183 * * *$ & $(2.90)$ & $0.326 * * *$ & $(5.87)$ \\
\hline $\begin{array}{l}\text { Place of work in 2001: Edinburgh or Glasgow vs the rest of Scotland } \\
\text { (including other large urban areas) }\end{array}$ & $0.141 *$ & $(1.88)$ & $0.378 * * *$ & $(5.58)$ \\
\hline $\begin{array}{l}\text { Place of residence in 2001: large urban areas (including Edinburgh } \\
\text { and Glasgow) vs the rest of Scotland }\end{array}$ & 0.016 & $(0.28)$ & $-0.113 * *$ & $(-2.16)$ \\
\hline $\begin{array}{l}\text { Place of residence in 2001: Edinburgh or Glasgow vs the rest of } \\
\text { Scotland (including other large urban areas) }\end{array}$ & 0.083 & $(1.10)$ & $-0.173 * *$ & $(-2.52)$ \\
\hline Migration: Change of address $>40 \mathrm{~km}$ vs change of address $<40 \mathrm{~km}$ & 0.002 & $(0.02)$ & -0.013 & $(-0.13)$ \\
\hline
\end{tabular}

Note: $* * *, * *, *$ denote statistical significance at $1 \%, 5 \%$, and $10 \%$ level, respectively. Numbers in parentheses are $\mathrm{t}$ values. ATT: the average treatment effect on the treated. The outcome is job status change between 2001 and 2011. The treatment is working in large urban areas for model 1, working in escalator regions for model 2, living in large urban areas for model 3, living in escalator regions for model 4, and the presence of migration for model 5. Edinburgh, Glasgow, and other large urban areas are combined to generate a treatment group. Logit models are used to calculate the propensity scores, and bootstrapping is used to obtain standard errors for the matching estimators. Other variables included in the logit models are the same with those in Table 2. Single nearest-neighbour matching is used.

Source: Authors' analysis of SLS.

In an attempt to substantiate this conclusion, further robustness tests were carried out to investigate whether movement into particular labour markets as opposed to movement per se was associated with subsequent occupational mobility. However these interaction models still do not provide evidence of spatial mobility leading to occupational mobility: only some moves to live and/or work in Glasgow were significant, and even then only at the unconvincing 90 per cent confidence level (Table 5). A lack of independent variation between place of residence and work could potentially explain the null findings in Tables 3 and 5. However additional analysis, not displayed here but available upon request, negates this possibility. There is thus only very tentative evidence that spatial mobility towards Scotland's biggest city is a determinant of subsequent career progression, above and beyond the benefits that those already living/working there receive in that respect. 
Table 5: Interaction effects, regressions of job status change (main effect and interaction)

\begin{tabular}{|c|c|c|c|c|}
\hline & \multicolumn{4}{|c|}{ Job status change } \\
\hline & \multicolumn{2}{|c|}{ Men only (7) } & \multicolumn{2}{|c|}{ Women only (8) } \\
\hline Individual \& regional variables (main effect) & \multicolumn{2}{|c|}{ Yes } & \multicolumn{2}{|c|}{ Yes } \\
\hline Live in Glasgow * Change of address & 0.300 & $(0.78)$ & $0.644^{*}$ & $(1.68)$ \\
\hline Live in Edinburgh $*$ Change of address & 0.137 & $(0.45)$ & -0.060 & $(-0.20)$ \\
\hline Live in other large urban area $*$ Change of address & -0.086 & $(-0.34)$ & -0.187 & $(-0.75)$ \\
\hline Work in Glasgow $*$ Change of address & $0.559 *$ & $(1.85)$ & -0.020 & $(-0.06)$ \\
\hline Work in Edinburgh $*$ Change of address & 0.074 & $(0.25)$ & 0.184 & $(0.60)$ \\
\hline $\begin{array}{l}\text { Work in other large urban area * Change of address } \\
\text { Place of residence/work interacting with other } \\
\text { individual variables (educational qualification and } \\
\text { knowledge-intensive index) }\end{array}$ & \multicolumn{2}{|c|}{ Yes } & \multicolumn{2}{|c|}{ Yes } \\
\hline Intercept & $12.788 * * *$ & $(65.54)$ & $9.875^{* * *}$ & $(56.88)$ \\
\hline Adjusted R2 & 0.311 & & 0.274 & \\
\hline $\mathrm{N}$ & 27296 & & 28198 & \\
\hline
\end{tabular}

Determinants of occupational mobility: by skill group

The analysis thus far has modelled the drivers of the career progress of all workers in Scotland over the period 2001-2011, and found little evidence in support of geographic mobility determining subsequent occupational mobility. However the literature suggests that it in fact the careers of higher skilled workers that are most sensitive to the escalator effects offered by escalator regions (Gordon et al, 2015; Newbold and Brown, 2012). To test this thesis, the study sample was split to enable investigation of the determinants of social mobility from three distinct starting points on the occupational hierarchy (in high, intermediate and low skill occupations in 2001, Table 6). 
Table 6: Regressions of job status change (by different skill groups, main effect only)

\begin{tabular}{|c|c|c|c|c|c|c|c|c|c|c|c|c|}
\hline & \multicolumn{4}{|c|}{ High-skill occupation in 2001} & \multicolumn{4}{|c|}{ Intermediate-skill occupation in 2001} & \multicolumn{4}{|c|}{ Low-skill occupation in 2001} \\
\hline & \multicolumn{2}{|c|}{ Men only (9) } & \multicolumn{2}{|c|}{ Women only (10) } & \multicolumn{2}{|c|}{ Men only (11) } & \multicolumn{2}{|c|}{ Women only (12) } & \multicolumn{2}{|c|}{ Men only (13) } & \multicolumn{2}{|c|}{ Women only (14) } \\
\hline Glasgow & -0.020 & $(-0.18)$ & -0.009 & $(-0.09)$ & -0.166 & $(-1.35)$ & $-0.215^{* *}$ & $(-2.16)$ & $-0.174 * *$ & $(-2.16)$ & $-0.246^{* * *}$ & $(-3.44)$ \\
\hline Edinburgh & 0.135 & $(1.17)$ & $-0.278^{* *}$ & $(-2.49)$ & -0.039 & $(-0.24)$ & -0.094 & $(-0.78)$ & 0.099 & $(0.69)$ & 0.040 & $(0.33)$ \\
\hline Other large urban area & 0.079 & $(1.07)$ & 0.048 & $(0.74)$ & -0.119 & $(-1.49)$ & -0.050 & $(-0.79)$ & 0.009 & $(0.14)$ & -0.050 & $(-0.96)$ \\
\hline \multicolumn{13}{|c|}{ Place of work in 2001 (Reference: the rest of Scotland) } \\
\hline Glasgow & $0.237^{* * *}$ & (2.74) & $0.438^{* * *}$ & $(5.43)$ & 0.084 & $(0.75)$ & $0.291^{* * *}$ & (3.36) & 0.048 & $(0.47)$ & $0.386^{* * *}$ & $(3.85)$ \\
\hline Edinburgh & $0.186^{*}$ & $(1.80)$ & $0.568^{* * *}$ & $(5.24)$ & 0.047 & $(0.32)$ & 0.141 & $(1.31)$ & -0.028 & $(-0.20)$ & -0.099 & $(-0.83)$ \\
\hline Other large urban area & $0.279^{* * *}$ & $(2.92)$ & $0.219^{* *}$ & $(2.33)$ & 0.054 & $(0.44)$ & $0.292 * * *$ & $(2.96)$ & -0.019 & $(-0.18)$ & 0.099 & $(1.09)$ \\
\hline Change of address $>40 \mathrm{~km}$ & -0.104 & $(-1.04)$ & 0.020 & $(0.21)$ & 0.193 & $(1.18)$ & 0.184 & $(1.30)$ & 0.194 & $(1.31)$ & -0.045 & $(-0.44)$ \\
\hline Knowledge-intensive index & $1.995^{* * *}$ & $(11.37)$ & $0.888^{* * *}$ & $(5.43)$ & $0.734 * * *$ & $(2.68)$ & $0.930^{* * *}$ & (5.93) & $0.893 * * *$ & $(3.44)$ & $1.178^{* * *}$ & $(9.85)$ \\
\hline \multicolumn{13}{|l|}{ Education (Reference: non-degree) } \\
\hline Degree & $1.628 * * *$ & $(21.75)$ & $1.628^{* * *}$ & $(21.07)$ & $1.089^{* * *}$ & $(8.39)$ & $1.007^{* * *}$ & $(9.15)$ & $0.803^{* * *}$ & $(4.04)$ & $1.013^{* * *}$ & $(6.63)$ \\
\hline HE diploma & $0.736^{* * *}$ & $(7.92)$ & $1.050^{* * *}$ & $(10.22)$ & $0.706^{* * *}$ & $(6.03)$ & $0.493^{* * *}$ & $(5.63)$ & $0.956^{* * *}$ & $(5.19)$ & $0.871^{* * *}$ & $(6.30)$ \\
\hline \multicolumn{13}{|c|}{ Place of birth (Reference: Scotland) } \\
\hline The rest of the UK & 0.054 & $(0.59)$ & $0.148^{*}$ & $(1.66)$ & 0.012 & $(0.09)$ & -0.124 & $(-1.28)$ & -0.064 & $(-0.56)$ & -0.003 & $(-0.04)$ \\
\hline The rest of the world & 0.148 & $(0.82)$ & 0.011 & $(0.07)$ & -0.098 & $(-0.37)$ & 0.162 & $(0.71)$ & -0.246 & $(-1.29)$ & 0.134 & $(0.72)$ \\
\hline Non-white & -0.068 & $(-0.16)$ & 0.041 & $(0.11)$ & 0.183 & $(0.29)$ & 0.103 & $(0.25)$ & 0.454 & $(1.35)$ & 0.063 & $(0.16)$ \\
\hline Other individual characteristics & \multicolumn{2}{|c|}{ Yes } & \multicolumn{2}{|l|}{ Yes } & \multicolumn{2}{|l|}{ Yes } & \multicolumn{2}{|l|}{ Yes } & \multicolumn{4}{|c|}{ Yes } \\
\hline Intercept & $19.347^{* * *}$ & $(40.63)$ & $17.586^{* * *}$ & $(43.52)$ & $11.873^{* * *}$ & $(27.86)$ & $9.468^{* * *}$ & $(23.54)$ & $9.971^{* * *}$ & $(22.39)$ & $7.743 * * *$ & $(19.81)$ \\
\hline Adjusted R2 & 0.305 & & 0.311 & & 0.211 & & 0.131 & & 0.171 & & 0.130 & \\
\hline $\mathrm{N}$ & 10587 & & 10318 & & 6405 & & 7564 & & 6721 & & 8751 & \\
\hline
\end{tabular}

The results show that the escalator effects of being located in a large urban labour market are chiefly applicable to higher skilled groups, and exert a relatively strong effect on women's career trajectories. More specifically, high skilled female workers in Edinburgh, Glasgow, and other large urban areas on average have upward mobility $0.568,0.438$, and 0.219 log points, respectively, faster than their counterparts in the rest of Scotland. The career progression 20012011 of those already in high skilled positions in 2001 benefits from working in a large urban area, whereas this is largely not the case for those in lesser skilled positions (except women working in Glasgow). These effects are especially strong for female levels of occupational mobility, where the impact of working in Edinburgh and Glasgow is particularly noteworthy. Whilst showing that the escalator effects of working in a city operate chiefly for higher skilled workers (especially women), the contents of Table 6 do not contradict the earlier finding concerning spatial mobility. In line with Gordon (2015), this suggests that all workers in big cities benefit from escalator effects, not just those who have moved there in search of enhanced career progression. This finding is further supported by model results when only place of residence or place of work is included in the models (Table 7). 


\begin{tabular}{|c|c|c|c|c|c|c|c|c|c|c|c|c|}
\hline & \multicolumn{4}{|c|}{ High-skill occupation in 2001} & \multicolumn{4}{|c|}{ Intermediate-skill occupation in 2001} & \multicolumn{4}{|c|}{ Low-skill occupation in 2001} \\
\hline & \multicolumn{2}{|c|}{ Place of residence only } & \multicolumn{2}{|c|}{ Place of work only } & \multicolumn{2}{|c|}{ Place of residence only } & \multicolumn{2}{|c|}{ Place of work only } & \multicolumn{2}{|c|}{ Place of residence only } & \multicolumn{2}{|c|}{ Place of work } \\
\hline & $\begin{array}{c}\text { Men only } \\
\text { (15) }\end{array}$ & $\begin{array}{l}\text { Women } \\
\text { only (16) }\end{array}$ & $\begin{array}{c}\text { Men only } \\
\text { (17) }\end{array}$ & $\begin{array}{c}\text { Women } \\
\text { only (18) }\end{array}$ & $\begin{array}{c}\text { Men only } \\
\text { (19) }\end{array}$ & $\begin{array}{l}\text { Women } \\
\text { only (20) }\end{array}$ & $\begin{array}{l}\text { Men only } \\
(21)\end{array}$ & $\begin{array}{l}\text { Women } \\
\text { only (22) }\end{array}$ & $\begin{array}{c}\text { Men only } \\
\text { (23) }\end{array}$ & $\begin{array}{c}\text { Women } \\
\text { only (24) }\end{array}$ & $\begin{array}{c}\text { Men only } \\
\text { (25) }\end{array}$ & \\
\hline \multicolumn{13}{|c|}{ Place of residence in 2001 (Reference: the rest of Scotland) } \\
\hline Glasgow & $\begin{array}{l}0.054 \\
(0.50)\end{array}$ & $\begin{array}{l}0.196^{* *} \\
(2.17)\end{array}$ & & & $\begin{array}{l}-0.134 \\
(-1.18)\end{array}$ & $\begin{array}{l}-0.056 \\
(-0.65)\end{array}$ & & & $\begin{array}{l}-0.154 * * \\
(-2.21)\end{array}$ & $\begin{array}{l}-0.057 \\
(-0.92)\end{array}$ & & \\
\hline Edinburgh & $\begin{array}{l}0.204 * * \\
(2.12)\end{array}$ & $\begin{array}{l}0.074 \\
(0.90)\end{array}$ & & & $\begin{array}{l}-0.017 \\
(-0.13)\end{array}$ & $\begin{array}{l}-0.030 \\
(-0.32)\end{array}$ & & & $\begin{array}{l}0.082 \\
(0.67)\end{array}$ & $\begin{array}{l}-0.026 \\
(-0.29)\end{array}$ & & \\
\hline Other large urban area & $\begin{array}{l}0.150^{* *} \\
(2.11)\end{array}$ & $\begin{array}{l}0.139^{* *} \\
(2.28)\end{array}$ & & & $\begin{array}{l}-0.102 \\
(-1.37)\end{array}$ & $\begin{array}{l}0.049 \\
(0.85)\end{array}$ & & & $\begin{array}{l}0.009 \\
(0.16)\end{array}$ & $\begin{array}{l}-0.005 \\
(-0.11)\end{array}$ & & \\
\hline \multicolumn{13}{|c|}{ Place of work in 2001 (Reference: the rest of Scotland) } \\
\hline Glasgow & & & $\begin{array}{l}0.240^{* * *} \\
(2.96)\end{array}$ & $\begin{array}{l}0.453 * * * \\
(6.39)\end{array}$ & & & $\begin{array}{l}0.015 \\
(0.15)\end{array}$ & $\begin{array}{l}0.201^{* * *} \\
(2.72)\end{array}$ & & & $\begin{array}{l}-0.029 \\
(-0.32)\end{array}$ & $\begin{array}{l}0.21 \\
(2.5\end{array}$ \\
\hline Edinburgh & & & $\begin{array}{l}0.243^{* * *} \\
(2.83)\end{array}$ & $\begin{array}{l}0.392 * * * \\
(4.97)\end{array}$ & & & $\begin{array}{l}0.049 \\
(0.41)\end{array}$ & $\begin{array}{l}0.103 \\
(1.26)\end{array}$ & & & $\begin{array}{l}0.037 \\
(0.31)\end{array}$ & $\begin{array}{l}-0.0 \\
(-0.1\end{array}$ \\
\hline Other large urban area & & & $\begin{array}{l}0.301^{* * *} \\
(3.27)\end{array}$ & $\begin{array}{l}0.253^{* * *} \\
(2.85)\end{array}$ & & & $\begin{array}{l}0.009 \\
(0.08)\end{array}$ & $\begin{array}{l}0.274 * * * \\
(2.91)\end{array}$ & & & $\begin{array}{l}-0.006 \\
(-0.06)\end{array}$ & $\begin{array}{l}0.07 \\
(0.8\end{array}$ \\
\hline Individual variables & Yes & Yes & Yes & Yes & Yes & Yes & Yes & Yes & Yes & Yes & Yes & \\
\hline Intercept & $\begin{array}{l}19.404 * * * \\
(40.68)\end{array}$ & $\begin{array}{l}17.807 * * * \\
(44.18)\end{array}$ & $\begin{array}{l}19.358^{* * *} \\
(40.71)\end{array}$ & $\begin{array}{l}17.625 * * * \\
(43.67)\end{array}$ & $\begin{array}{l}11.877 * * * \\
(27.86)\end{array}$ & $\begin{array}{l}9.420^{* * *} \\
(23.43)\end{array}$ & $\begin{array}{l}11.841 * * * \\
(27.79)\end{array}$ & $\begin{array}{l}9.412 * * * \\
(23.46)\end{array}$ & $\begin{array}{l}9.964 * * * \\
(22.44)\end{array}$ & $\begin{array}{l}7.698^{* * *} \\
(19.68)\end{array}$ & $\begin{array}{l}9.948 * * * \\
(22.34)\end{array}$ & $\begin{array}{l}7.6 \varepsilon \\
(19 .\end{array}$ \\
\hline Adjusted R2 & 0.304 & 0.307 & 0.305 & 0.31 & 0.211 & 0.129 & 0.211 & 0.131 & 0.171 & 0.128 & 0.170 & 0.12 \\
\hline $\mathrm{N}$ & 10587 & 10318 & 10587 & 10318 & 6405 & 7564 & 6405 & 7564 & 6721 & 8751 & 6721 & 875 \\
\hline
\end{tabular}

\section{Discussion and conclusions}

The overarching aim of this study has been to contribute to understandings of how individual and place characteristics, and geographic mobility, act together to influence career progression, as measured through the concept of occupational mobility. The most original findings relate to the importance of locational effects in these dynamics, with the statistical modelling demonstrating that place matters in terms of one's propensity to move up the occupational hierarchy. The spatial sophistication of analysis was innovative in this respect since it shows that workplace is a much better predictor of occupational mobility than place of residence (the conventional measure of place effects). This distinction is important since, as the case of Glasgow illustrates, many individuals reside outside the boundaries of cities but commute to and work in them. Changing migration-commuting thresholds (how a worker negotiates the relationship between place of work and place of residence) could potentially explain some of the findings reported in this paper. Research thus needs to be sensitive to how commuting patterns might skew analyses of the role of place in career progression. A possible way forward in this respect could be to incorporate Travel to Work Areas (TTWAs) into statistical models, and thus integrate city regions with their commuting hinterlands. At the aggregate level in Scotland, longer distance commutes increased only marginally between the 2001 and 2011 censuses $(12.5 \%$ and $13.6 \%$ of commutes respectively were $20 \mathrm{~km}+)$ whereas the proportion of movers was fairly constant over this period $(11.6 \%$ and $11.3 \%$ of the population changed address in 2000-2001 and 2010-2011 respectively). 
A core component of this research was the potential role that spatial mobility plays in social mobility. Whilst the descriptive statistics (Table 1) inferred that those who moved in 19912001 subsequently experienced higher rates of upward occupational mobility 2001-2011 than those who did not move, the presence of migration was not a significant determinant of career progression in the statistical models used in this analysis. These findings fit with existing research in other spatial contexts in that it suggests that larger urban areas offer opportunities for accelerated occupational mobility for those who work there (Brown and Newbold, 2012), regardless of whether or not they migrated there. These place effects were strongest for those already near the top of the occupational hierarchy and for women. Therefore in Scotland, as elsewhere, highly skilled migrants benefit from the escalator effects offered by particular regions (Findlay et al, 2008; Newbold and Brown, 2012) but no more so than the well-educated residents already working in them (Gordon, 2015). The spatially uneven nature of labour market opportunities has implications for efforts to promote a meritocracy: to gain optimal career progression one must not only be highly skilled, but must also work in (through originally residing in or commuting or migrating to) specific types of places. Locational factors thus exert a significant enabling, and also constraining, influence on the ability and propensity of individuals to achieve upward occupational mobility. This leads to the pertinent question of whether the spatial mobility of able workers towards escalator regions should be facilitated, or whether the currently increasing spatial disparities in earnings in many countries should be the focus of greater policy attention.

Being well-educated, being employed in a knowledge intensive sector and working in a large urban area are therefore the key determinants of occupational mobility, irrespective of migration experiences. The fact that these place effects are particularly strong for women's career progression is an aspect of the research that is particularly intriguing and that merits further attention. Whilst necessary to overcome the issue of causality, a limitation of the study is that it may have underestimated the role of spatial mobility in occupational mobility, given the time periods under consideration (migration 1991-2001 and subsequent job status change 2001-2011). Ceiling effects also mean that the analysis is potentially less sensitive to the career progress of workers already in high ranking occupations relative to that of those in lower ranking jobs. The selection bias and omitted variable problem (e.g. role of unobserved ability in career progression) is another methodological challenge that this research has not been able to completely overcome. Finally, more geographically sensitive analyses could help to identify 
potential interesting sector specific escalator effects. For example the city of Aberdeen may offer particular types of accelerated career progress as a consequence of its concentration of jobs in the oil and gas sector. However potential challenges associated with low cells counts has necessitated the aggregation of geographic areas in this investigation.

In addition to the substantive findings listed above, the study has also responded to calls for methodological innovations within the burgeoning mobilities paradigm (Findlay et al, 2015). Firstly, it has demonstrated how estimates of wage levels can be applied to census based datasets in order to generate more sophisticated measures of job status change. Secondly, by using relatively small geographical units the research highlights and underlines the importance of refined spatial indicators in these types of analyses, as demonstrated by the difference between the influence of place of work and place of residence on career progression. Thirdly, the analysis underlines the extent to which place based determinants of occupational mobility are structured according to gender, with escalator effects being particularly evident for highly skilled females in larger urban areas. A fruitful avenue for future research would be to seek explanation for why escalator effects play out differently for men and women. Fourthly, by focusing on Scotland the investigation confirms that escalator effects can occur beyond core global city regions. Finally, by investigating occupational mobility over the period 2001-2011 the research is one of the first studies to cover a period post the 2008 financial crash. Future research could examine how this period of economic change and uncertainty has impacted on patterns and processes of social mobility, perhaps drawing on the recently instigated UK Household Longitudinal Study for example.

\section{References}

Abreu, M., Faggian, A., \& McCann, P. (2014). Migration and inter-industry mobility of UK graduates. Journal of Economic Geography, 15, 353-385.

Blossfeld, H. P., \& Hakim, C. (Eds.). (1997). Between equalization and marginalization: Women working part-time in Europe and the United States of America. New York: Oxford University Press.

Boyle, P. J., Feijten, P., Feng, Z., Hattersley, L., Huang, Z., Nolan, J., \& Raab, G. (2009). Cohort profile: the Scottish longitudinal study (SLS). International Journal of Epidemiology, $38(2), 385-392$. 
Brown, W., \& Newbold, K. (2012). Cities and Growth: Moving to Toronto - Income Gains Associated with Large Metropolitan Labour Markets. Statistics Canada. Economic Analysis Division.

Bruegel, I. (2000). The restructuring of London's labour force: migration and shifting opportunities 1971-1991. Area, 32(1), 79-90.

Champion, T. (2012). Testing the return migration element of the 'escalator region' model: an analysis of migration into and out of south-east England, 1966-2001. Cambridge Journal of Regions, Economy and Society, 5, 255-269.

Crawford, C., Johnson, P., Machin, S., \& Vignoles, A. (2011). Social Mobility: A Literature Review. Report for UK Government, Department for Business, Innovation and Skills.

Dex, S., Ward, K., \& Joshi, H. (2008). Gender differences in occupational wage mobility in the 1958 cohort. Work, Employment and Society, 22(2). 263-280.

Dibben, C., \& Clemens, T. (2012). Estimating an occupational based wage in the census: A mixed model approach to generate empirical bayes estimates. Edinburgh, 1-11.

Fielding, A. J. (1992). Migration and Social Mobility: South East England as an Escalator Region. Regional Studies, 26 (1), 1-15.

Fielding, A. J. (2007). Migration and social mobility in urban systems: national and international trends. In H. Geyer (ed) International Handbook of Urban Policy Volume 1 Contentious Global Issues (107-137). Edward Elgar: Cheltenham.

Fielding, A. T., \& Halford, S. (1993). Geographies of opportunity: a regional analysis of gender-specific social and spatial mobilities in England and Wales, 1971-81. Environment and Planning A, 25, 1421-1440.

Findlay, A., Mason, C., Harrison, R., Houston, D., \& McCollum, D. (2008). Getting off the escalator? A study of Scots out-migration from a global city region. Environment and Planning A, 40(9), 2169-2185.

Findlay, A., Mason, C., Houston, D., McCollum. D,, \& Harrison, R. (2009). Escalators, Elevators and Travelators: The Occupational Mobility of Migrants to South-East England. Journal of Ethnic and Migration Studies, 35(6), 861-879.

Findlay, A. McCollum, D. Coulter, R. and Gayle, V. (2015). 'New Mobilities Across the Life Course: a Framework for Analysing Demographically Linked Drivers of Migration'. Population, Space and Place 21(4). pp 390-402.

Fleming, C., Kifle, T., \& Kler, P. (2016). Immigrant occupational mobility in Australia. Work, Employment and Society 30(5). pp 876-889. 
Fraser of Allander Institute. (2015). Scotland's Economic Powerhouses. Available at: https://www.scottishcities.org.uk/site/assets/files/1221/foa -

_scotland_27s_economic powerhouses_-28-10-15_1.pdf

Accessed $3^{\text {rd }}$ May 2017.

Friedmann, J. (1986). The world city hypothesis. Development and Change, 17, 69-83.

Glaeser, E., \& Maré, D. (2001). Cities and Skills. Journal of Labor Economics, 19(2), 316342.

Glick Schiller, N. and Salazar, N. (2013). 'Regimes of Mobility Across the Globe'. Journal of Ethnic and Migration Studies 39:2. pp 183-200

Gordon, I. (2015). Ambition, Human Capital Acquisition and the Metropolitan Escalator. Regional Studies, 49(6), 1042-1055.

Gordon, I., Champion, T., \& Coombes, M. (2015). Urban escalators and interregional elevators: the difference that location, mobility, and sectoral specialisation make to occupational progression. Environment and Planning A, 47, 588-606.

Halfacree, K. (2012). 'Heterolocal Identities? Counter - Urbanisation, Second Homes, and Rural Consumption in the Era of Mobilities'. Population, Space and Place 18. pp 209-224.

Härkönen, J., \& Bihagen, E. (2011). Occupational attainment and career progression in Sweden. European Societies, 13(3), 451-479.

Kalir, B. (2013). 'Moving Subjects, Stagnant Paradigms: Can the 'Mobilities Paradigm' Transcend Methodological Nationalism?' Journal of Ethnic and Migration Studies 39:2. pp 311-327,

King, R. (2012). 'Geography and migration studies: Retrospect and prospect'. Population, Space and Place 18. pp 134-153.

King, R., Lulle, A., Parutis, V., \& Saar, M. (2015). Young Baltic Graduates Living and Working in London: From Peripheral Region to Escalator Region in Europe. Sussex Centre for Migration Research. Working Paper No. 82.

Lindstrom, D., \& Ramírez, A. (2010). Pioneers and Followers: Migrant Selectivity and the Development of U.S. Migration Streams in Latin America. Annals of the American Academy of Political Social Science, 630(1), 53-77.

Lipset, S. M., and Bendix, R. (1959). Social Mobility in Industrial Society. Berkeley: University of California Press. 
Manzoni, A., Harkonen, J., \& Mayer, K. U. (2014). Moving on? A growth-curve analysis of occupational attainment and career progression patterns in West Germany. Social Forces, 92(4), 1285-1312.

Newbold, K., \& Brown, W. (2012). Testing and Extending the Escalator Hypothesis: Does the Pattern of Post-migration Income Gains in Toronto Suggest Productivity and/or Learning Effects? Urban Studies, 49(15), 3447-3465.

Ng, T., Sorensen, K., Eby, L., \& Feldman, D. (2007). Determinants of job mobility: A theoretical integration and extension. Journal of Occupational and Organizational Psychology, $80,363-386$.

Nickell, S. J. (1982). 'The determinants of occupational success in Britain'. Review of Economic Studies 49. pp 43-53

Office for National Statistics. (2017a). NOMIS local authority profile: Edinburgh. Available

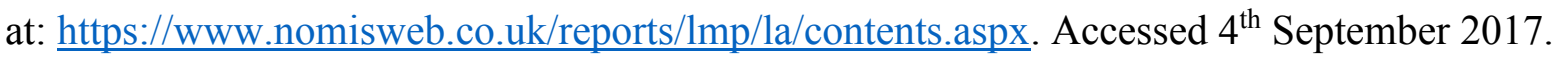

Office for National Statistics. (2017b). NOMIS local authority profile: Glasgow. Available at: https://www.nomisweb.co.uk/reports/lmp/la/contents.aspx. Accessed $4^{\text {th }}$ September 2017.

Reuschke, D. (2015). Self-Employment as a Route In and Out of Britain's South East. Regional Studies, 49(4), 665-680.

Roosaar, L., Mõtsmees, P., \& Varblane, U. (2014). Occupational mobility over the business cycle. International Journal of Manpower, 35(6), 873-897.

Rooth, D., \& Ekberg, J. (2006). Occupational Mobility for Immigrants in Sweden. International Migration, 44(2), 57-77.

Rosenbaum, P., \& Rubin. D. (1983). The Central Role of the Propensity Score in Observational Studies for Causal Effects. Biometrica, 70(1), 1-55.

Savage, M. (1988). The Missing Link? The Relationship between Spatial Mobility and Social Mobility. The British Journal of Sociology, 39(4), 554-577.

Sheller, M. and Urry, J. (2006). 'The new mobilities paradigm'. Environment and Planning A 38. pp 207-226

Sicherman, N., \& Galor, O. (1990). A Theory of Career Mobility. Journal of Political Economy, 98(1), 169-192. 
Tolsma, J., \& Wolbers, M. (2014). Social origin and occupational success at labour market entry in the Netherlands, 1931-80. Acta Sociologica, 57(3), 253-269.

van Ham, M., Findlay, A., Manley, D., \& Feijten, P. (2012). Migration, Occupational Mobility, and Regional Escalators in Scotland. Urban Studies Research, 2012, 1-15.

van Ham, M., \& Manley, D. (2015). Occupational Mobility and Living in Deprived Neighbourhoods: Housing Tenure Differences in 'Neighbourhood Effects'. Applied Spatial Analysis and Policy, 8, 309-324.

Wooldridge, J. (2012). Introductory Econometrics: A Modern Approach (5 ${ }^{\text {th }}$ Edition). OH: South-Western Cengage Learning.

Xu, W., Tan, K. C., \& Wang, G. (2006). Segmented local labor markets in postreform China: Gender earnings inequality in the case of two towns in Zhejiang province. Environment and Planning A, 38, 85-109. 